\title{
THE RESISTANCE ASPECT OF FISHING BOAT SKIPJACK POLE AND LINE
}

\author{
Wolter R. Hetharia ${ }^{1 *}$, Eliza R. de Fretes ${ }^{2}$ and Reico H. Siahainenia ${ }^{3}$ \\ 1Department of Naval Architecture - Faculty of Engineering, Pattimura University, Ambon 97233 \\ *Email: hethariawr@yahoo.com \\ 2Department of Naval Architecture - Faculty of Engineering, Pattimura University, Ambon 97233 \\ Email: defretes@gmail.com \\ ${ }^{3}$ Department of Naval Architecture - Faculty of Engineering, Pattimura University, Ambon 97233 \\ Email:ekoadvmal@gmail.com
}

\begin{abstract}
Abstrak. Pengoperasian kapal penangkap ikan cakalang turut andil dalam penangkapan ikan tuna dan cakalang khususnya di perairan Indonesia. Sebuah studi sebelumnya yang dilakukan oleh penulis menemukan bahwa tidak ada metode yang sesuai untuk perhitungan hambatan pada tahap desain kapal awal. Selain itu, ada trim awal pada kapal selama operasi yang berkontribusi terhadap resistensi. Tujuan dari penelitian ini adalah untuk mengetahui perbedaan hambatan antara model uji dan metode yang ada. Penelitian dilakukan juga untuk mengetahui pengaruh trim awal kapal. Studi dimulai dengan mengumpulkan database kapal induk kemudian dikembangkan dan ditransformasikan menjadi skala model untuk tujuan pengujian di tangki penarik. Hasil uji model dikonversi ke kapal skala penuh. Hambatan kapal skala penuh dihitung berdasarkan metode Holtrop dan Guldhammer. Hasil full-of resistance yang diperoleh dari uji model dan metode dikumpulkan, dievaluasi dan dibandingkan. Hasil penelitian menunjukkan adanya perbedaan resistansi untuk semua metode. Hasil pengujian model lebih besar $21 \%$ dibandingkan dengan metode Holtrop pada kecepatan layan 10 knot. Sedangkan hasil pengujian model lebih rendah $14 \%$ dibandingkan dengan metode Gulhammer pada kecepatan yang sama. Selain itu, pada kecepatan 10 knot trim awal 0,50 meningkatkan 5\% resistensi, trim awal 10 meningkatkan $10 \%$ resistensi dan trim awal 20 meningkatkan 16\% resistensi dibandingkan dengan kapal tanpa trim awal. Kesimpulannya, metode resistensi yang ada tidak cocok untuk diterapkan pada kapal penangkap ikan cakalang pole and line. Selain itu, trim awal berkontribusi untuk meningkatkan resistensi dan harus dihindari selama operasi kapal.
\end{abstract}

Kata kunci: metode resistensi, efek trim

\begin{abstract}
The operation of fishing vessels skipjack pole and line contributes in catching tuna and skipjack fishes particularly in Indonesian waters. A previous study conducted by the authors found that there was no suitable method provided for the resistance computation atearly ship design phase. Besides, there was aninitial trim existed on the vessel during the operation which contributes for the resistance. The purpose of the study is to find the difference of resistance between the model test and the existing methods. The study was executed also to find the effect of initial trim of the vessel. The study began with collecting the database of a parent ship then to develop and transform into a model-scale for testing purpose in the towing tank. The results of model test were converted to the full-scale vessel. The resistance of full-scale vessel was computed based on the Holtrop and Guldhammer methods. The result of full-of resistance obtained from the model test and the methods were collected, evaluated and compared. The results showed the difference of the resistance for all methods. The result of model test is greater $21 \%$ than that of Holtrop method at the service speed of 10 knots. Meanwhile, the result of model test is lower $14 \%$ than that of Gulhammer method at the same speed. In addition, at the speed of 10 knots the initial trim of $0.5^{\circ}$ increase $5 \%$ ofthe resistance, the initial trim of $1^{O}$ increase $10 \%$ of resistance and the initial trim of $2^{\circ}$ increase $16 \%$ of resistance compared to the vesselwithout initial trim. In conclusion, the existing resistance methods are not suitable to be applied for skipjack pole and line fishing vessels. In addition, the initial trim contributes to increase the resistance and should be avoided during the vessel operation.
\end{abstract}

Keywords: resistance methods, trim effects 


\section{INTRODUCTION}

The Indonesian waters contain a lot of Tunas and Katsuwonus Pelamis. By the benefit of the geographical condition which is located at the cross of continents and oceans, the Indonesian waters have the potential of such kind of big pelagic fishes. These fishes are caught by skipjack pole and line fishing vessels to fulfill the domestic and international market demanding. In fact, those vessels are built by local boat makers without considering some technical aspects required in ship design procedures. One ship parameter that should be considered is the resistance. This parameter will impact the ship engine power, fuel consumption and the ship operational cost. Ship resistance database is not available for this kind of vessels due to their unique configurations. In fact, some methods are still applied for the resistance computation as an approach. In addition, the vessels operate in initial trim conditions where this phenomena affects the vessels' resistance. The initial trim condition occurs due to different of vessels' load arrangement.

The research was conducted by the authors in order to find the resistance based on the model test compared to that was obtained from the available methods. In addition, the initial trim effect occurred at the vessels duringthe operation was investigated by conducting the model test to find the resistance effect. The initial trim effect for the resistance was varied for several degree levels. This level can reach $2^{\mathrm{O}}$ of trim at an extreme operation condition. The resistance results of the model test were converted to the full-scale vessels. In addition, other parameters such as trim behavior and engine power will be determined during the model test. A full-scale skipjack pole and line fishing vessel of MV Zamirun was selected and used as a prototype. The vessel were developed further for model test procedure and requirements. The results of model tests were presented to be applied for future consideration of resistance aspect.

\section{MATERIAL AND METHOD}

\subsection{Theoretical Background}

When a shipis moving through a still water surface with speed of $\mathrm{V}_{\mathrm{S}}$, it needs an Effective Horsepower (EHP) to overcome the total resistance $\left(\mathrm{R}_{\mathrm{TS}}\right)$ acting on its opposite direction. The effective horsepower comes from the main engine which is known as the Brake Horsepower (BHP). The power transfer from BHP to EHP have some losses. The ratio of EHP/BHP is represented as PC (Propulsive Coefficient) which consists of: the hull efficiency $\left(\eta_{H}\right)$, the propeller efficiency $\left(\eta_{\mathrm{O}}\right)$, the relative rotation efficiency $\left(\eta_{R}\right)$, the shaft efficiency $\left(\eta_{\mathrm{S}}\right)$ and the transmission efficiency $\left(\eta_{\mathrm{T}}\right)$. This relation is represented by the following formula [1]:

$$
\mathrm{BHP}=\mathrm{EHP} / \mathrm{PC}=\mathrm{R}_{\mathrm{TS}} \times \mathrm{V}_{\mathrm{S}} / \eta_{\mathrm{H}} \eta_{\mathrm{O}} \eta_{\mathrm{R}} \eta_{\mathrm{S}} \eta_{\mathrm{T}}
$$

The total resistance $\mathrm{R}_{\mathrm{TS}}$ consists of some components interact one-another in a complicated ways. In practical way, those components may be classified as 2-D frictional resistance $\left(R_{F}\right)$ and residuary resistance $\left(R_{R}\right)[1,2,3]$ :

$$
\begin{aligned}
\mathrm{R}_{\mathrm{TS}} & =\mathrm{R}_{\mathrm{FS}}+\mathrm{R}_{\mathrm{RS}}=0.5 \rho \mathrm{C}_{\mathrm{TS}} \mathrm{S} \mathrm{V}_{\mathrm{S}}^{2} \\
& =0.5 \rho\left(\mathrm{C}_{\mathrm{FS}}+\mathrm{C}_{\mathrm{RS}}+\mathrm{C}_{\mathrm{A}}\right) \mathrm{S}_{\mathrm{S}} \mathrm{V}_{\mathrm{S}}^{2} \\
\mathrm{C}_{\mathrm{FS}} & =0.075 /\left(\log _{10} \mathrm{Rn}_{\mathrm{S}}-2\right)^{2}
\end{aligned}
$$

where:

$\mathrm{C}_{\mathrm{TS}}=$ Total resistance coefficient

$\mathrm{C}_{\mathrm{RS}}=$ Residuary resistance coefficient (from statistical data or model experiment).

$\mathrm{C}_{\mathrm{FS}}=2$-DFlat-platefrictional coefficient, obtained from the ITTC 57 model-ship correlation line

$\mathrm{C}_{\mathrm{A}}=$ Correlation allowance .

$\mathrm{S}_{\mathrm{S}}=$ Wetted surface area of the ship

$\mathrm{Rn}_{\mathrm{S}}=$ Reynolds number of the ship

$\mathrm{Rn}_{\mathrm{S}}=\mathrm{V}_{\mathrm{S}} \mathrm{L}_{\mathrm{S}} / \mathrm{v}$

$\mathrm{L}_{\mathrm{S}}=$ Length of the ship

$v_{\mathrm{S}}=$ Kinematics viscosity of fluid,

$\rho_{\mathrm{S}}=$ Specific mass of fluid.

$\mathrm{S} \quad=$ Subscript for ship \& M for model.

\subsection{The Procedure of Model Experiment.}

The experiment of ship model in order to findthe parameter ofship resistance and effective horsepower should be conducted by fulfilling all aspects and procedures starting from designing ship's model up to predict the results to the fullscale ship. The hydrodynamic aspects that should be included are dimensional analysis, laws of comparisons and model-ship correlation of resistance [1-7]. The dimensional analysis results inthe Pi-theorem where in form of nondimensional is represented as:

$$
\mathrm{C}_{\mathrm{T}}=\mathrm{C}_{\mathrm{F}}(\mathrm{Rn})+\mathrm{C}_{\mathrm{R}}(\mathrm{Fn})
$$

The coefficient of total resistance $\left(\mathrm{C}_{\mathrm{T}}\right)$ consists of frictional resistance coefficient $\left(\mathrm{C}_{\mathrm{F}}\right)$ and the residuary resistance coefficient $\left(\mathrm{C}_{\mathrm{R}}\right)$. In addition, the effects of forces in fluid movement give Froude Law of similarity and is formulated as:

$$
[\mathrm{Fn}]_{\mathrm{M}}=[\mathrm{Fn}]_{\mathrm{S}}
$$

The correlation of model-ship gives a nondimensional relationship where the coefficient of 
total resistance $\mathrm{C}_{\mathrm{T}}$ which is a function of $\mathrm{Fn}$ and $\mathrm{Rn}$ may be separated as:

$$
\mathrm{C}_{\mathrm{T}}(\mathrm{Rn}, \mathrm{Fn})=\mathrm{C}_{\mathrm{F}}(\mathrm{Rn})+\mathrm{C}_{\mathrm{R}}(\mathrm{Fn})
$$

The results of model experiment nondimensionally is represented as:

$$
\left(\mathrm{C}_{\mathrm{R}}\right)_{\mathrm{M}}=\left(\mathrm{C}_{\mathrm{T}}\right)_{\mathrm{M}}-\left(\mathrm{C}_{\mathrm{F}}\right)_{\mathrm{M}}
$$

The aspect of model-ship correlation gives also a Froude assumption which states that the residuary resistance coefficient of model equals to that of the ship. In non-dimensional form, it is represented as:

$$
\left(\mathrm{C}_{\mathrm{R}}\right)_{\mathrm{M}}=\left(\mathrm{C}_{\mathrm{R}}\right)_{\mathrm{S}}
$$

The prediction of total resistance of ship from the results of model experiment is represented nondimensionally in the relationship:

$$
\left(\mathrm{C}_{\mathrm{T}}\right)_{\mathrm{S}}=\left(\mathrm{C}_{\mathrm{R}}\right)_{\mathrm{M}}+\left(\mathrm{C}_{\mathrm{F}}\right)_{\mathrm{S}}+\mathrm{C}_{\mathrm{A}}
$$

\subsection{Resistance Computation Based on Holtrop Method}

Holtrop method requires the total resistance composed on viscous and wave resistances [8,9].

$$
\mathrm{R}_{\mathrm{T}}=1 / 2 \rho \mathrm{V}^{2} \mathrm{~S}_{\mathrm{tot}}\left[\mathrm{C}_{\mathrm{F}}(1+\mathrm{k})+\mathrm{C}_{\mathrm{A}}\right]+\mathrm{R}_{\mathrm{W}} / \mathrm{WxW}
$$

Where:

$\mathrm{C}_{\mathrm{F}} \quad$ = coeficient of fristional resistance

$\mathrm{C}_{\mathrm{A}}=$ corellation allowance

$(1+\mathrm{k})=$ the form factor

$\mathrm{R}_{\mathrm{W}} \quad=$ wave resistance

$\mathrm{W}=$ weight displacement.

$\mathrm{V} \quad=$ ship speed

$\mathrm{S}_{\mathrm{tot}}=$ wetted surface area

\subsection{Resistance Computation Based on Guldhammer Method}

A series of resistance curves published by Guldhammer and Harlvald is collected from the resistance test of the towing tanks [10]. The total resistance is expressed as follows:

$$
\mathrm{R}_{\mathrm{T}}=0,5 \mathrm{C}_{\mathrm{T}} \rho \mathrm{S} \mathrm{V} \mathrm{V}^{2}
$$

where the total resistance coefficient $\mathrm{C}_{\mathrm{T}}$ consists of

$$
\begin{aligned}
C_{T}= & C_{F}+C_{R}+C_{A} \\
C_{F}= & \text { coeficient of fristional resistance } \\
C_{R}= & \text { residuary resistance coefficient obtained } \\
& \text { from the curves provided by Guldhammer } \\
C_{A}= & \text { corellation allowance. }
\end{aligned}
$$

\subsection{Prediction of Model Test to Full-Scale Ship}

The results of model test are presented in the form of total resistance coefficient of model $\left(\mathrm{C}_{\mathrm{TM}}\right)$ and residuary resistance coefficient of model $\left(\mathrm{C}_{\mathrm{RM}}\right)$.

$$
\mathrm{C}_{\mathrm{TM}}=\mathrm{R}_{\mathrm{TM}} /\left(0,5 \rho_{\mathrm{M}} \mathrm{S}_{\mathrm{M}} \mathrm{V}_{\mathrm{M}}^{2}\right)
$$

$$
\mathrm{C}_{\mathrm{RM}}=\mathrm{C}_{\mathrm{TM}}-\mathrm{C}_{\mathrm{FM}}
$$

where, $\mathrm{C}_{\mathrm{FM}}$ was obtained from the ITTC 57 frictional line. Using Froude's Assumption where $\mathrm{C}_{\mathrm{RS}}=\mathrm{C}_{\mathrm{RM}}$ then the total resistance for full-scale ship will be:

$$
\mathrm{R}_{\mathrm{TS}}=0,5 \rho\left(\mathrm{C}_{\mathrm{FS}}+\mathrm{C}_{\mathrm{RM}}+\mathrm{C}_{\mathrm{A}}\right) \mathrm{S}_{\mathrm{S}} \mathrm{V}_{\mathrm{S}}^{2}
$$

A correlation allowance $C_{A}$ will be added for fullscale ship which account for the extrapolation factor and surface roughness of full-scale ship.

\subsection{Design of Ship Model}

The design of ship models should be based on hydrodynamic and technical aspects [1-5, 7]. Basic hydrodynamic aspects such asthe dimensional analysis, the laws of comparison and the correlation of ship-model should be fulfilled. The effects such as blockage, side wall interference and shallow water effect should be avoided. The dimension and geometrical hull form of the modelare obtained from the full-scale ship in determining the resistance of designed ship. During the process of developing the model, a parameter of ship-model ratio $\lambda$ which is ratio of $\mathrm{L}_{\mathrm{S}} / \mathrm{L}_{\mathrm{M}}$ was used to determine the dimensions and configuration of the model.

\subsection{The Steps of Model Testing}

The steps are recommended to be followed in conducting the model test: The facilities provided in the towing tank should satisfy all requirements for model test. The load cell was calibrated as a standard procedure in model test. The turbulence stimulator was used to create a turbulence flow. The model was tested for a volume displacement and $\mathrm{L}_{\mathrm{CB}}$ suited to full-scale ship. The model was set in the trimming tank to achieve an even keel condition at the design draft. The center of towing force should be in line with propeller thrust line. Data acquisition was executed by collecting the results of testing such as speed, resistance trim and fluid properties. The effects such as tank wall interference, blockage and shallow water should be avoided during the test.

\subsection{The Data of Parent Ship.}

One parent fishing vessel skipjack pole and line which is MV. Zamirun was introduced in this study. The dimensions and configuration of the vessel are presented at Table 1 . The ship models were constructed manually from the material of 
plywood and wood filler. A ratio of $\lambda$ was set 10 for MV. Zamirun.

Table 1. Dimension of the Parent Ship and Model

\begin{tabular}{llcc}
\hline \multirow{2}{*}{ No } & \multicolumn{1}{c}{ Ship Parameters } & \multicolumn{2}{c}{$\lambda=10$, speed 10 kt } \\
\cline { 3 - 4 } & & $\begin{array}{c}\text { Full-Scale } \\
\text { Ship }\end{array}$ & Model \\
\hline 2 & Length Overall, LOA $(\mathrm{m})$ & 21.60 & 2.160 \\
\hline 3 & Length Bet. Perpend., $\mathrm{L}_{\mathrm{BP}}(\mathrm{m})$ & 17.35 & 1.735 \\
\hline 4 & Length of Waterline, LwL $(\mathrm{m})$ & 18.92 & 1.892 \\
\hline 5 & Breadth, B $(\mathrm{m})$ & 4.00 & 0.400 \\
\hline 6 & Breadth Overall, BOA $(\mathrm{m})$ & 5.00 & 0.500 \\
\hline 7 & Draft, $\mathrm{T}(\mathrm{m})$ & 1.50 & 0.150 \\
\hline 8 & Deck Height, $\mathrm{D}(\mathrm{m})$ & 2.05 & 0.205 \\
\hline 9 & Service Speed, Vs $(\mathrm{kt}), \mathrm{m} / \mathrm{sec}$ & 9.70 & 1.576 \\
\hline 10 & Froude Number, Fn & 0.382 & 0.382 \\
\hline 11 & Block Coefficient, $\mathrm{C}_{\mathrm{B}}$ & 0.484 & 0.484 \\
\hline 12 & Midship Coefficient, $\mathrm{C}_{\mathrm{M}}$ & 0.726 & 0.726 \\
\hline 13 & Prismatic Coefficient, $\mathrm{C}_{\mathrm{P}}$ & 0.677 & 0.677 \\
\hline 14 & Waterplane Coefficient, $\mathrm{C}_{\mathrm{W}}$ & 0.753 & 0.753 \\
\hline 15 & Volume Displacement, $\nabla\left(\mathrm{m}^{3}\right)$ & 53.50 & 0.053 \\
\hline 16 & Weight Displacement, $\Delta(\mathrm{t})$ & 54.84 & 0.055 \\
\hline 17 & Wetted Surface Area, $\mathrm{S}\left(\mathrm{m}^{2}\right)$ & 88.40 & 0.884 \\
\hline 18 & Long. Center of Buoyancy, $\mathrm{L}_{\mathrm{CB}}(\mathrm{m})$ & +0.755 & +0.075 \\
\hline & & & \\
\hline
\end{tabular}

\subsection{Constructing of The Model}

Constructing of model was started by drawing a set of lines plan then, this configuration was plotted to wooden planks for the next steps which were cutting the waterlines and frames. Frames and waterlines were set together to make hull of models. Handling sand process was required toachieve an accuracy dimensions and smooth surface of models. The final coating and painting were applied to avoid humidity of models (Figure 1). Turbulence stimulators type of pins were attached at $5 \%$ LBP from FP.
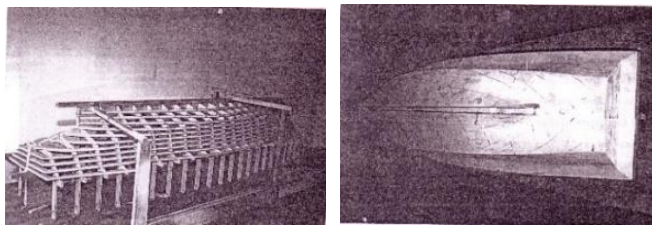

Figure 1. Constructing the Model

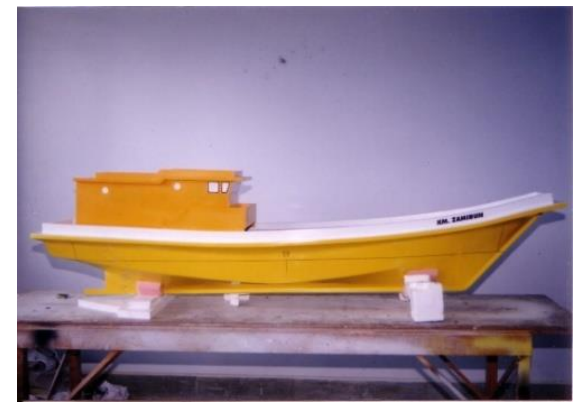

Figure 2. Model Skipjack Pole and Line

\subsection{Executing The Model Test.}

The test was conducting at The Towing Tank of Faculty of Engineering, Pattimura University, Ambon. The facility is equipped with resistance dynamometer, towing guides with trim meters, speed control, clamp apparatus and measurement devices. All test activities were operated directly on the carriage (Figure 3). A turbulence stimulator type of pins were attached at frame 19 to generate turbulence flow around models' hull. The data of resistance and trim were recorded by recording instruments. During the test, the model was set to be free of heave and trim but, it was restricted to yaw, sway, surge and roll.
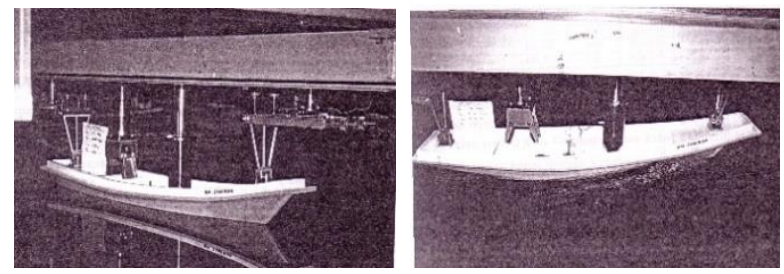

Figure 3. Model Test

All data were collected as follows:

- Speed of carriage and model was controlled and measured by speed meter ( $\mathrm{m} / \mathrm{second})$

- Resistance force was measured by load cell of resistance dynamometer (volt)

- Fore and aft trims were measured by trim meter, attached at trim guides (volt)

- Fluid temperature measured during the test.

\section{RESULTS AND DISCUSSION \\ 3.1. The Results of Model Test.}

The results of resistance were presented in term of the resistance coefficients as shown in Figure 4. The resistance coefficients were obtained directly from model test. Using Froude assumption $\mathrm{C}_{\mathrm{RS}}=$ $\mathrm{C}_{\mathrm{RM}}$ and $\mathrm{C}_{\mathrm{T}}=\mathrm{C}_{\mathrm{F}}+\mathrm{C}_{\mathrm{R}}$ then prediction for full-scale ships can be done. The trim level for the model and full-scale parent shipis presented in Figure 5. This trim effects exist when there are some external factors when the ship is in operation condition. 


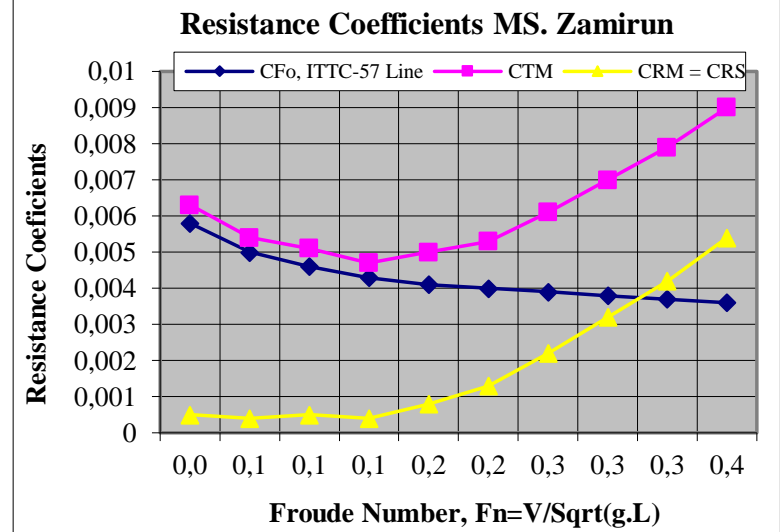

Figure 4. Resistance Coefficients of Model

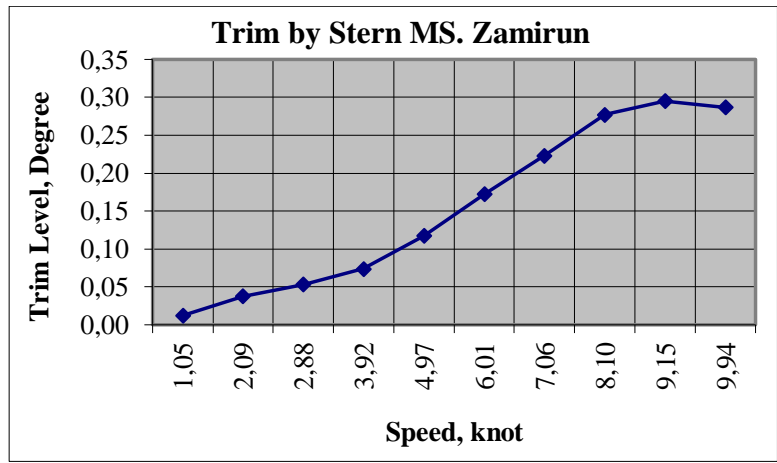

Figure 5. Trim Level of the Full-Scale Ship

\subsection{Prediction for The Full-Scale Ship}

The full-scale ship resistance is presented in Figure 6 while the Effective Horsepower is presented in Figure 7.

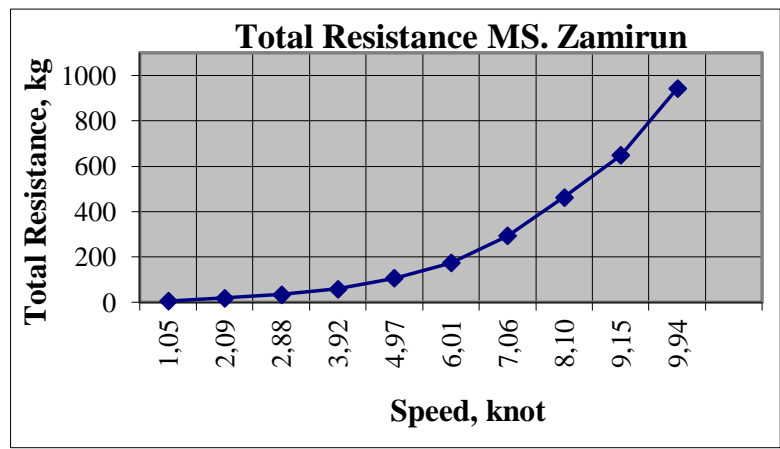

Figure 6. Total Resistance of Full-Scale Ship

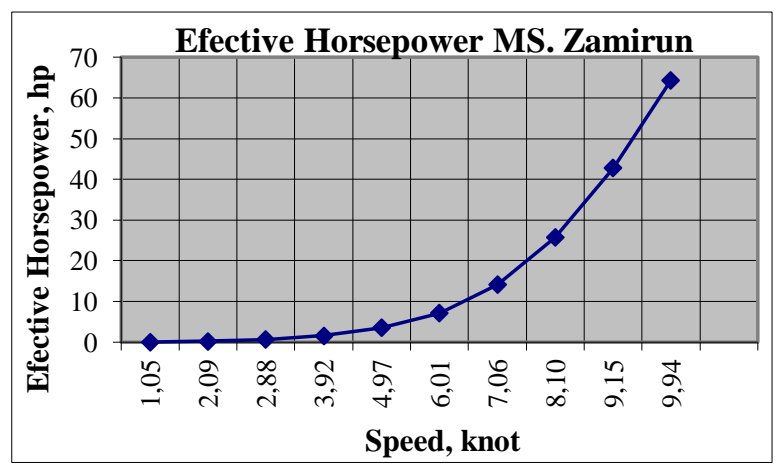

Figure 7. Effective Horsepower of Full-Scale Ship

\subsection{The Resistance from The Existing Methods}

The results of computation of the resistance based on the existing methods are presented at Figure 8. In this study, two existing methods were used namely the Holtrop and Guldhammer methods. Figure 8 shows the existence of total ship resistance of two methods and result from model test.

\subsection{Initial Trim Effect on Ship Resistance}

The trim effect was evaluated during the test. The scenario of initial trim effects was developed for trim $0^{\mathrm{O}}$ (even keel condition), trim by stern $0.5^{\circ}$, trim by stern $1^{\mathrm{O}}$ and trim by stern $2^{\mathrm{O}}$. The result of trim effect is presented in Figure 9.

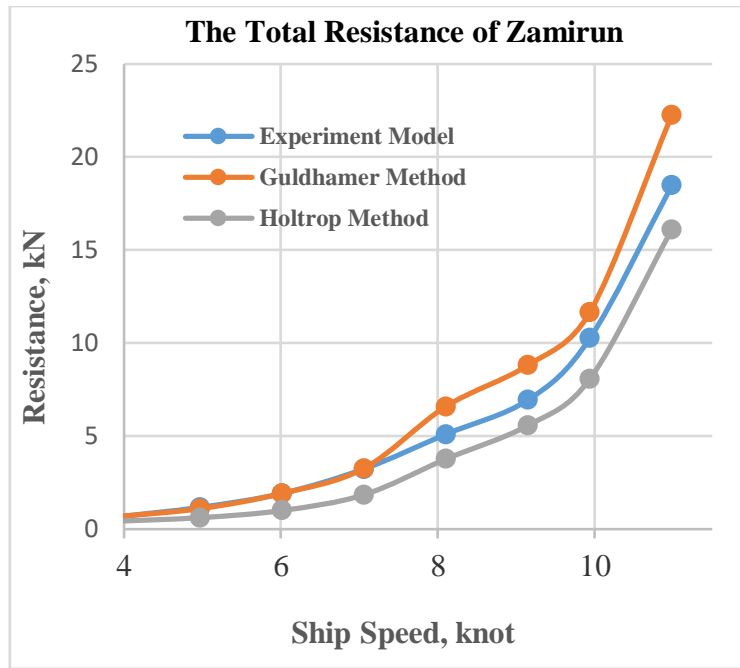

Figure 8. The Resistance from Existing Methods

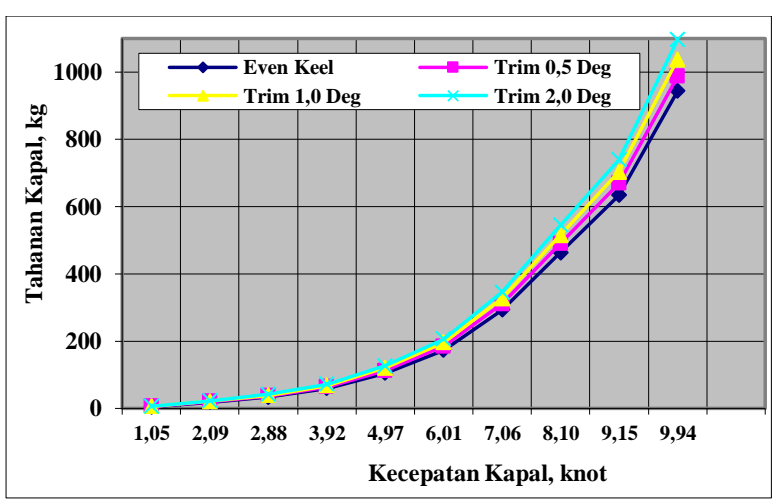

Figure 9. Effect of Initial Trim for the Resistance

\subsection{Discussion}

The study on model test was executed based on the proper requirements and test procedures to ensurethe best test results. The model construction was developed in a proper way to guarantee the performance of model resistance. The calibration of load cell dynamometer to ensure data acquisition during the test. The results of model test show proper resistance curves as showed in 
Figure 4. It is also shown the residuary resistance curve is obtained as a result of the total resistance deduced to the frictional line.The frictional line was obtained from the ITTC-57 frictional line. Meanwhile, the trim effect due to hydrodynamic forces around the hull can be seen in Figure 5 where the higher the speed the higher trim by stern. The predictions of full-scale resistance and effective horsepower are presented in Figures 6 and 7. This prediction was based on the Froude assumption.

Figure 8 describes concerning the difference of the resistance based on the model test compared to the existing resistance methods. It is clear that the result of model test is higher than that of Holtrop method but lower than that of Guldhammer method for a range of lower to higher speeds. At the service speed of 10 knots, the resistance based on model test is higher $21 \%$ compared to the result of Holtrop Method. Meanwhile, the resistance based on model test is lower $14 \%$ compared to that of Guldhammer method at the same service speed. In this case, some doubts concerning those two existing methods are arising due to the fact that those two methods are not suitable for skipjack pole and line fishing boat. On the other hand, the results of model tests are usually used to confirm the existing methods or some computational results.

Figure 9 describes the effects of initial trim to the ship resistance. The variation of initial trim gives the difference of the resistance for a range of speed as presented by the resistance curves. This phenomena will end-up with the increasing of ship power and operational cost. It can be drawn from the curves that the effect of $0.5^{\circ}$ initial trim can increase the resistance varied from $9 \%$ to $5 \%$. Also, $1^{\mathrm{O}}$ initial trim can increase the resistance varied from $15 \%$ to $10 \%$. Meanwhile, $2^{\mathrm{O}}$ initial trim can increase the resistance varied from $23 \%$ to $16 \%$. At the service speed of 10 knots the initial trim of $0.5^{\circ}$ contributes the additional resistance of $5 \%$ while initial trim $1^{\mathrm{O}}$ contributes $10 \%$ and $2^{\mathrm{O}}$ contributes $16 \%$.

\section{CONCLUSION AND RECOMMENDATION}

\subsection{Conclusion}

It can be concluded from the study that:

- The application of the existing resistance methods for the fishing boat skip-jack pole and line may be not appropriate. This is due to the configuration of hull form which is not suitable for the existing resistance methods.

- Compared to the Holtrop method, the resistance of model test is higher for a range of speed numbers and at the service speed of 10 knots this value is $21 \%$.

- The resistance result based on the model test is lower than that of Guldhammer method and at the service this value is $14 \%$.

- Generally, the initial trim contributes to the increasing of resistance compared to that of even keel condition for a range of speed numbers. The higher initial trim the higher the resistance can be obtained

- At the ship speed of 10 knots, the increase of resistance is $5 \%$ for initial trim $0.5^{\circ}, 10 \%$ for initial trim of $1^{\circ}$ and $16 \%$ for initial trim $2^{\circ}$.

\subsection{Recommendation}

- It should be considered more for the future application of using the existing resistance methods for skipjack pole and line fishing boat.

- The operation of skipjack pole and line fishing boats should be avoided the initial trim to avoid the excessive trim effect in order to reduce the resistance

\section{REFERENCES}

[1]. Lewis, E. V., 1988, Principles of Naval Architecture, Vol. II, Ship Resistance and Propulsion, SNAME, Jersey City, N.J.

[2]. Cough, R.B., et. al., (1984), The Use of Model Basins in The Design of Ships and Marine Structures, SNAME Proceedings Ninth Ship Technology and Research (STAR) Symposium.

[3]. Moor, D. I. and Silverleaf, A., (1960), A Procedure for Resistance and Propulsion Experiments with Ships, Proceeding of the Symposium on the Towing Tank Facilities Instrumentation and Measuring Techniques, Paper No. 19, Yugoslav Ship Hydrodynamics Institute Publication, Zagreb

[4]. Newman, J. N., (1977), Marine Hydrodynamics, The MIT Press, Cambridge, Massachusetts.

[5]. Harvald, Sv. Aa, (1983), Resistance and Propulsion of Ships, John Wiley \& Sons Publication, Denmark.

[6]. Rawson, K. J., and Tupper, E. C., (1984), Basic Ship Theory, Vol. 2, $3^{\text {rd }}$ Edition, Longman Group Ltd., London.

[7]. Clayton, B. R. and Bishop, R. E. D., (1982), Mechanics of Marine Vehicles, J.W. Arrowsmith Ltd, Great Britain. 
[8]. Holtrop, J., 1989, “ A Statistical Re-Analysis of Resistance and Propulsion Data", Delft University of Technology, Delft

[9]. Molland, A. F., Turnock, S. R., and Hudson, D. A., 'Ship Resistance and Propulsion Practical Estimation of Ship Propulsive
Power', Cambridge University Press, 32 Avenue of the Americas, New York, USA, 2011.

[10]. Guldhammer, H. E. and Harvald, Sv. Aa., 1974, Ship Resistance, Akademsik Forlag, Copenhagen. 